\title{
A lost war in living memory: Japan's Second World War
}

\author{
HARUKO TAYA COOK* and THEODORE F. COOK \\ *Fordham University, Marymount College, Tarrytown, NY 10591, USA. \\ E-mail: Hcook@fordham.edu; 'William Paterson University, Wayne, \\ New Jersey 07470, USA. E-mail: CookT@wpunj.edu
}

We examine the strata of memory in Japan's recollections of the wartime experience and explore the shaping and releasing of memory in Japan, seeking to penetrate and recover individual Japanese experience. Individual memories that seemed tightly contained, when released were told with great emotional intensity and authenticity. That there has been little public discourse does not mean that individual Japanese have forgotten that war, but that the conflict - a war with no generally accepted name or firmly fixed start or end - seems disconnected from the private memories of the wartime generation. Japan was defeated thoroughly and completely, and in the history of memory we see no well-established narrative form for telling the tale of the defeated. In Japan's public memory of the war, War itself is often the enemy, and the Japanese its victims. Such a view is ahistorical and unsatisfactory to nations and peoples throughout Asia and the Pacific. The prevailing myths during Japan's war, developed and fostered over 15 years of conflict, and the overwhelming weight of more than three million war dead on the memories of the living forged a link between a desire to honour and cherish those lost and the ways the war is recalled in the public sphere. Enforced and encouraged by government policies and private associations, protecting the dead has become a means of avoiding a full discussion of the war. The memorials and monuments to the Dead that have been created throughout Japan, Asia, and the Pacific stand silent sentry to a Legend of the war. This must be challenged by the release into the public sphere of living memories of the War in all their ambiguity, complexity, and contradiction without which Japan's Memory can have no historical veracity. Moreover, the memories of the Second World War of other peoples can never be complete without Japan's story.

\section{Introduction}

Japan's war ended on 15 August 1945, when the Japanese Emperor announced 
to his people that he had accepted the demands of the Allies and called on his military forces to lay down their arms. Japan today officially recalls 'the War' with a government-sponsored 'Day Commemorating the End of the War' each year on the anniversary of that announcement, at precisely noon each 15 August. It is not a National holiday, but on that day the Nihon Budōkan Hall in Tokyo (normally the site of concerts, professional wrestling matches, and martial arts events) is transformed into the venue for a 'National Ceremony to Mourn the War Dead'. Seated facing great banks of white and yellow chrysanthemums, the Prime Minister, government figures, local officials and selected representatives of the 'families of the war dead' are among the several thousand invited. The Emperor reads a short statement broadcast live on radio and television, and a minute of silence is observed precisely at noon. Akihito, the present Emperor, has now succeeded his father, the Shōwa Emperor, Hirohito, in this role.

The Tokyo ceremony is not used to discuss the reasons for the war, nor to debate its causes, costs, or consequences. This brief observance, unlike those of that long ago war, contains no overt religious elements. It is accompanied neither by ringing speeches in honour of the valiant men and women who fought for Japan, nor paeans to the memory of the bravery and suffering of those who died at home or endured agonies in the war's wake. In 1993, a comment by then Prime Minister Hosokawa Morihiro that the Second World War was an 'aggressive war' raised a brief commotion, but there was no real change even under his successor, a Social Democrat. No apologies or regrets are offered to the millions throughout the Asian-Pacific region who survived the depredations of the Japanese, and few seem to consider that amiss. In an uncompromisingly solemn tone, the ceremony to remember the dead confirms the participants in their generally mute and passive state. The national memorial service held for the more than three million Japanese who died in the War portrays the event as a past tragedy to be mourned, instead of as a huge event in national history to be understood and explained. It does not initiate or contribute to a public discourse about why Japan fought, or why Japan has been held responsible by its neighbours for what happened.

In that strangely disembodied official ceremony, the lost war seems anchored in neither time nor public memory. For younger Japanese, the vast majority of whom were born long after 15 August 1945, the day to mourn the war dead has become a 'seasonal event' signifying high summer, like the cry of the cicada or the call of the goldfish seller. It is difficult to find many young people who even pause for the moment of silence that is the only national commemoration of the event. Inside the Hall, however, we see the faces of people who lived through those years; by the rules of invitation, they must have lost a family member in that war. Yet how they died or what caused their lives to be lost, are not questions to be raised on such an occasion. There is no way for an onlooker to know what stories these relatives of the dead might have to tell. 
For us, the ceremony in its historical opaqueness seemed to capture much of what was both tantalizing and initially forbidding in our decision to begin the project that became Japan at War: An Oral History. ${ }^{1}$ As the annual event rolled around each year, and we, like so many others, took a few moments off to watch the ceremony, or at least, view clips of it on the evening news, we had often wondered about these people and their experiences, so rarely discussed except for the few weeks in August around the 15 August anniversary. They and the war seem hardly mentioned at all in the media. In 1988, we determined that we wanted to ask the wives, brothers, sisters, or the few remaining parents, aunts and uncles of a generation whose lives had ended half a century or more ago for their stories, and for those of their dead relatives, before those with direct memory of the war years themselves died. It was not only of the dead that we wanted to learn; we planned to ask the living: what was the war like for Japanese soldiers, sailors, workers, farming wives, factory girls, and school children, how did they survive, what motivated them, what were the wartime feelings they could not openly express, and what did they learn from their ordeal?

In one sense, our book on the Japanese war proved to be a 'memory book', in the way American writer Studs Terkel used the term - a collection of recollections by ordinary people, recalling events as they remembered them, confided to interviewers seeking out their personal memories of events of which they were a part or in which they were enmeshed. Academic writing on the history of memory has used the notion differently, but we would contend that to understand how the Second World War has become a part of Japan today, it is essential to learn how it is remembered by those who experienced it. ${ }^{2}$

In Japan, as we have noted, the War is not celebrated, and in many ways it is not even commemorated. But the Dead are recalled, if briefly, in the national event in Tokyo, in parallel ceremonies at Chidorigafuchi and Yasukuni Shrine, and throughout the country in local observances. These events are not overtly 'Lieux de mémoire, or mnemonic sites, embodying concrete traces of the past, visible and durable signs of its celebration', as Pierre Nora has called them. ${ }^{3}$ But they are both temporal and physical portals through which we may glimpse the textures of the memories in Japan. ${ }^{4}$

\section{The survival and value of wartime myths}

Why can we not yet describe a conscious dialogue with the past of Japanese, or indeed students of Japan outside Japan concerning the Second World War? ${ }^{5}$ In contrast, Samuel Hynes ${ }^{6}$ stated that the First World War in Britain, besides being 'the greatest military and political event of its time ..., was also the great imaginative event.' 
It altered the ways in which men and women thought not only about war, but about the world, and about culture and its expressions... No one after the war - no thinker or planner, no politician or labour leader, no writer or painter - could ignore its historical importance or frame his thought as though the war had not occurred, or had been simply another war.

In the post-1945 period, despite a few novels and a few movies, no one yet has created a narrative of defeat in modern war that can be accepted as compelling to many who experienced that conflict. We must look at how the war was presented to the Japanese people as it was fought, to understand more precisely how empty this leaves the Japanese narrative. ${ }^{7}$ The official description of Japan's purpose and experience, current in Japan during the conflict, was a product of a long period of evolution and refinement. Emperor Hirohito referred to it in the Declaration of War by looking back on His Imperial Grandsire, the Meiji Emperor, as the motive force in the development of the Great Japan which went to war with the West. What we may call 'The Wartime Myth,' with allowances for changes over time and fortunes of war, it ran something like this: loyal Japanese men, sent off by faithful and devoted women and parents, go to war to preserve and protect their Imperial nation, divine in inspiration, ruled over by the latest in a line of Emperors stretching back 2600 years to Jimmu. These men, 'the emperor's soldiers' are willing to die for the Imperial Nation, secure in the belief that, should they fall in battle, their spirits will be enshrined and honoured by their families and even by their Emperor in the Yasukuni Shrine.

The Wartime Myth of Japan continues. Reluctantly, Japan is forced to take up arms against a recalcitrant and unredeemable China, which is backed by the selfish and scheming United States and Britain who seek to prevent Japan from winning their sacred war in China and are conspiring to keep the peoples of Asia enslaved. They are fighting after December 1941 not only for their nation, but they are fighting for the liberation of all Asia from the West and the creation of the Greater East Asia Co-Prosperity Sphere. In this struggle they are joined by the enlightened peoples and patriots of the former colonial areas who seek to learn from their Japanese older brothers how best to accomplish the tasks of development. Behind the soldiers are the People of Japan as a whole, themselves united in the cause of their Emperor, loyal absolutely cleansed of impure and improper thoughts, 'One Hundred Million Bullets of Fire'.

The Wartime Myth was created largely by government fiat, and was coordinated, calculated, mobilized and subsidized. Artists, authors, journalists, photographers, cartoonists, poets, painters, sculptors all joined in. As the war situation changed, deteriorating within a year of Pearl Harbor, the patterns of thought changed. Horribly, these war myths were in large measure the Allied propaganda image and Allied War myth with the names changed! ${ }^{8}$

These war myths were in direct conflict with the individual's experience of the 
war itself. So far were these ideas from the catastrophes that overwhelmed Japan's military forces, civilian population, and national being, that the ideals and images of victory and advance were useless in support of the lost war. Yet it is not sufficient to argue that defeat completely invalidated their power, even for survivors of the war.

The Lost War required a totally different narrative, one which could account for, and explain, the horrors that were experienced by millions, something which could interpret and convey the sense of confusion, isolation, desolation, anguish, and desertion of Japanese people in the midst of the 'War as it Was'. The idea of an individual interpretation of the War Experience was itself a violation of the overriding principle of the Wartime Myth that Japan was a Nation United, working against individualism and selfishness, sacrificing for the collective and unconcerned about individual fate. So ill-prepared were Japanese for the truth of their situation, that most felt almost atomized. One of the men we met described how he, as a poorly trained soldier, fresh from college, found himself wandering around a shell-swept Saipan, peering hopefully into the diary of a war comrade, hoping to find even the faintest hint of dissatisfaction with the war so that he could broach the forbidden subject of surrender. Because the central unifying theme of the pre-war era and the central figure in the Wartime Myth, the Emperor, was not removed as a legitimate figure in the wake of Japan's defeat and surrender in 1945, the disjunction felt by many Japanese between individual experience and state ideology was not alleviated. Indeed, it remained difficult to criticize the State at all when the Emperor was described in the new, post-war constitution of Japan dictated by American Occupation authorities as a 'symbol of the unity of the people'. During the war, the attainment of the objectives of the war had been presented to the people of Japan as dependent upon their ultimate unity in support of their Emperor, while their sacrifices were portrayed by the state organs of propaganda as appropriate to alleviate the suffering of their ruler.

Fifty years after the crushing defeat of the Japanese empire in the Second World War, the values and language by which Imperial Japan justified and mobilized for its war still strongly affect, and deeply influence, the ways that Japanese today describe and understand that war. For many in the wartime generation - those who were adults when the war began, or reached the age of full mobilization during it, these values seem resurrected, re-emerging with little post-war transformation, when they speak of those times. ${ }^{9}$ So little in the public sphere stands between their war memories and the moment of their telling decades later, that the language of those war years comes immediately back to their lips. Again and again, such terms as gyokusai (sacrificial battles). okuni no tame ni (for the country's sake), Tokkō (special attack) and kamikaze (divine wind), Kempei (military police), Tennō no sekishi (the Emperor's children) are used with immediacy. Specialized wartime words - akagami (red paper, a call-up notice for military service), sanpachi jū 
(Type-38, the standard infantry rifle), imonbukuro (comfort bags, gifts for soldiers sent from the Homeland), bōkūzukin (air defence helmet, the padded cotton headgear universally worn in the cities by women and children late in the war) pop into sentences as if they were current slang.

The term gyokusai, for example, was first introduced into the Pacific War in May 1943, when American forces retook the outpost of Attu in the Aleutians, seized by the Japanese in the complex operation that had culminated in the Japanese Navy's disaster at Midway in June 1942. Made up from two ideographs with literal meanings of 'jewel' and 'smashed,' the word was derived from a sixth-century Chinese classic telling of the morally superior man who would elect to destroy his most precious possession rather than compromise his principles. ${ }^{10}$ Rather than the meaningless death of an island garrison overwhelmed by superior numbers and firepower, the final charge of the Japanese soldiers under Colonel Yamazaki on Attu island was transformed into an act of heroic self-sacrifice given the name 'Attu gyokusai'. The phrase had poetic resonance and soon caught on as a patriotic and emotion-charged euphemism with wide application. ${ }^{11}$

Intellectuals, including historians, writers, and educators, betray an analytical vagueness in many areas and appear willing to accept wartime values and descriptions of deaths without examination. The story of the 'gyokusai battle of Saipan' may be cited here as one example of how this was accomplished. The propaganda notion of gyokusai can remain in the historical record as if it were true, unexamined critically for decades, even as it grew in importance to become what historians argue about when discussing the war. Naturally, the apologists of the war, and those nostalgic for the 'lost values' they wish to find in the 'heroic self-sacrifice' of Japanese willing to fight to the end rather than surrender, elevate such battles - along with the Kamikaze Special Attack Forces - to the highest levels of their Valhalla. At the same time, critics of the military and 'progressive' historians and political groups have tended to see 'gyokusai battles' as examples of bad actions, stupidity, or proof of official callousness at the loss of human life in service to the Emperor. The exact events subsumed under such a term have rarely been the subjects of sufficient historical research to examine fully 'their true natures'.

The images conjured up by the term gyokusai have been frozen, partially because of the failure openly to examine and explore what happened at such well-known sites as Attu, Saipan or Leyte. The war Myth can be said to have been fought out in the spaces designated. There are the cliffs of Saipan, the caves of Okinawa or Iwo Jima, and the skies over the American fleet filled by the Kamikaze. These 'wartime spaces', are separated in time and in emotional universe, unlimited by time or physical space, where the truth about the war can be preserved, when values are as they were supposed to be, where memories lead not to recalled horrors, but to realized ideals. This war-Heaven is opposed to the 
war-Hell that is the foundation of the realities experienced by those who survived; it is the foundation for memories individuals feel occur in this world, and is often invoked when they seek to recover an idealized hope from the horrors and confusion of actual wartime experience.

The most important point to be made about the 'Saipan gyokusai' is that it did not happen! At least it did not occur in the way reported. Nor did what took place on Saipan - especially at Marpi Point and places now called in the tourist trade 'Banzai Cliff' - support the conclusion that all Japanese civilians, were prepared to die rather than surrender. Despite horrible scenes of suicide and murder, fear and misery, desperation and despair, this wasn't 'gyokusai'! Many thousands survived, most of them openly choosing surrender to death. Battered civilians in excess of 10000 and more than 1000 military men were captured and returned to Japan after the war. ${ }^{12}$

The impression left by the created Myth of what happened on Saipan in the summer of 1944, has had a profound imprint on official memories in both Japan and the Allied countries. More than any other event during the course of the war, with the exception of the atomic bombs themselves, the notion - engendered by propagandists - that the overwhelming majority of the Japanese civilian population of Saipan, largely women and children, willingly took their own lives rather than submit to the Americans, shaped the memory of the final year of the Pacific War. If this was 'The Nature of the Enemy' in the memorable title attached to Robert Sherrod's piece in Time magazine in July 1944, was not any force, any action, any act, no matter how criminal it might appear under normal circumstances, justified if it meant the annihilation of such thinking? Was it not essential to stop treating Japanese as rational beings, and proceed with the extermination of all, if necessary?

After the end of the war, the first repatriation ship carried about 1000 people to the Main Islands of Japan. Noda Mitsuhara, a sailor who was captured after the 'final charge' on 7 July, found his own grave had been erected back at home when he returned and his name erased from the family registration. ${ }^{13}$ In the second stage of repatriation, ten thousand other survivors, mostly civilians, were taken to Okinawa. The fate of the Koreans among the internees is still undetermined. ${ }^{14}$ All those survivors of the battle on Saipan were made into living ghosts by erasing them from the memory of the living world. A few returnees wrote their own books, but they are exceptions. Thousands came back, each individual who told his or her story was treated as 'a rare survivor' or a freak escapee from a 'universal fate'. 15

Rather than being cleared up, the myths around Saipan have multiplied and an even greater Myth has been created as the Japanese 'memory' has been incorporated into American 'memory' as the American war story has been told. ${ }^{16}$ One needs only to read current mass fiction in the United States, such as Tom 
Clancy's Debt of Honor to see the utility of the theme in race-based, national stereotypes of the 'enemy'. Perhaps less understandable, the historian and journalist, Denis Warner, a witness to Saipan, repeated what could have been a war dispatch, when writing on the occasion of the 50th anniversary of the landings in the International Herald Tribune. ${ }^{17}$

It is vital when considering the consequences of such thinking that we recall that most of the one million Japanese civilian casualties in the war, and perhaps more than half of the military deaths - well over one million - occurred in the last 12 months of the conflict. Between July 1944 and August 1945, as Japan's leaders sought to protect themselves and the institutions they claimed to serve, the people of Japan were in fact sacrificed under a National slogan that was eventually refined into 'One Hundred Million Die Together,' a natural extension of the illusory image of Saipan. Death became a tool useful for the survival of the Imperial System itself at the end of the Lost War.

\section{Death and memory}

If Japan's war remains wrapped in the shrouds of the dead, at the individual level, war responsibility is not clearly established in the minds of many Japanese today, no matter how certain the rest of the world may be about it. ${ }^{18}$ The Japanese people were not, in fact, held responsible for the war by the Allied occupation forces. The United Nations, through SCAP (Supreme Commander Allied Powers in the Pacific, General Douglas MacArthur's headquarters), tried, convicted and executed selected Japanese leaders and military figures for plotting an 'aggressive war' and for condoning and encouraging war crimes. The nature of Japanese responsibility for the war was further muddied when Emperor Hirohito, revered during the war as the figure from whom all authority to act was said to derive, was never charged. In fact, after declaring himself in January 1946 to be a human being and not divine, he continued in office under the new post-war constitution as 'the symbol of the unity of the people'.

While Japanese 'militarism', as embodied in military institutions, could be abolished, and the new Constitution might renounce war, there was no clear opportunity for the Japanese people as a whole to look at all the linkages between those who held power during the war and wartime behaviour. The Occupation authorities made efforts to reform the great industrial combines known as zaibatsu, but concentrated most of their efforts on the military. Through purges from public office and manipulation of the new Constitution, the Americans who led the Occupation sought to excise the institutions deemed most responsible for Japan's aggression, while exorcising the spirit of militarism from the body politic. ${ }^{19}$ The best, clearest, and most easily understood object for emotional 
reaction was removed when Emperor Hirohito seemed to receive the sanction of Japan's former enemies, when he ceased to be a target of war crimes prosecution.

Millions of Japanese who supported the national war effort to the last day, without any active substantive resistance against their government or military, found themselves amid the devastation of a defeated land reeling from personal loss. Larger questions of causality and responsibility were either passed along to the small group of convicted military leaders, politicians, industrialists, and bureaucrats singled out by the Allies, or deferred to the Occupation forces who replaced the authority of the military government. ${ }^{20}$ Sorting out the war experience, with some notable individual exceptions, found little place in the public sphere in a country where all that now seemed to matter was rebuilding and starting again. ${ }^{21}$ The issue of Imperial responsibility for the origins and execution of the war was left largely unexplored.

Emperor Hirohito never discussed the war with his own people. As a result, in the 44 post-war years of his reign, the Emperor whom the wartime generation had been taught to worship as a living god, and in whose name so many had died, never clearly accepted or assigned responsibility for the decisions that brought about the war. Despite the fact that the war was fought under his command, very few of the people we have interviewed mentioned him when they explained their experience, except for those who were in elementary school in those years, and grew up thinking of themselves as the 'Emperor's children'. When Emperor Shōwa Hirohito was mentioned, it was usually only with reference to his war responsibility. ${ }^{22}$

Despite the enormous number of deaths suffered in Japan's war, it was nearly impossible for Japanese suddenly to turn from the Wartime Myth of a beneficent Emperor to a denunciation of the entire 'national polity' as created and developed since the Meiji era, and affix blame on the Emperor. Millions of military men, officially 1.9 million, died between 1937 and 1945, with at least 2.3 million military dead overall. There were as many as one million civilians killed directly in the course of the war. Each of these fatal casualties left behind families who yearned to know what had happened to their dead. Every village, every town, and every city neighbourhood in Japan was home to fathers, sons, and brothers who died as soldiers and sailors in that war between 1937 and 1945. Their deaths were considered publicly to have been 'honourable deaths', deaths 'for the sake of the country', or 'in the name of the Emperor'. Such deaths had been invested with a purpose that would have been invalidated if the entire institutional structure of wartime Japanese society were rejected. Moreover, practically every individual Japanese had played a direct part in that process of patriotic fervour, at the ceremonial level at least, no matter what fears or doubts they may have harboured inside

Senshi - death in action, literally 'death in battle' - was the 'Good Death'. The 
dead had a special place in the consciousness of all Japanese in the wartime generation's memories of the war. Throughout the conflict, newspapers and newsreels, local governments, national organizations, and civilian groups from the national patriotic women's associations to the Neighbourhood Associations within individual hamlets or city wards, all placed a prime weight on the honouring of the dead who 'fell in battle'. Each soldier departing for the front, whether a new recruit, veteran reservist, or conscript, was usually sent off in public ceremonies to waving flags, and each was promised that they would be honoured on their return, or if they died their spirits would return to an honoured place in Yasukuni Shrine where even the Emperor promised to pay them homage. The soldiers in the later stages of the war increasingly had no hope of returning home, and more and more, their departure was celebrated as a wake as well as induction. Congratulations for being called to the colours were combined with expressions of gratitude and deference to those who were about to die.

In the case of the Kamikaze (the Tokkō or Special Attack Forces) such departures in 1945 were highly ritualized and widely publicized. In every town and village, boys, and young - and not-so-young - men marched off with the sombre meaning of their neighbour's and families' cheers in their hearts. Araki Shigeko, for example, had stood in a factory yard when the drone of aeroplanes approached, and all the young girls working there with her waved madly to the receding planes that dipped their wings overhead, bound for the South and for death. With her marriage a secret from all but her parents, Shigeko waved with a special fervour. She was the wife of a Special Attack Pilot in the Navy. A bride for only four hours before he had left for the last time, she had known her husband all her life. She confided to us that while she could look back on her last moments with her husband with longing,

... At that time, I thought it was natural that Haruo would die. It would have been shameful for him to go on living. I was half-waiting for his death. But I was waiting for his 'glorious and honorable death'. If he didn't die, it would be a disgrace. If a family lost someone in action in those days, we would congratulate them. We'd say, 'That's wonderful.' We really meant it! $!^{23}$

Even after the lost war, perhaps even more than had the war been victorious, it became the responsibility of the living - individual Japanese brothers, fathers, mothers, sisters, and children - to keep faith with the dead. The official notion of the war as a 'Sacred War' was totally repudiated by the Japan's conquerors without protest and with the tacit agreement of Japanese governments under the Occupation. The Myth of the War was degraded by academic intellectuals who created for themselves a special place outside of responsibility, from where they could safely attribute to themselves immunity from blame, while sanctifying their own motives and judgements. But, for each dead soldier, or civilian casualty, their 
Memory, the public reason they died notwithstanding, required nurturing in the most private of spaces, individual memory.

Ironically, the most public of venues for the memorialization of the dead in Japan, the Yasukuni Shrine in Tokyo, remains a vital centre for these individual memories. Today, Yasukuni claims to be solely dedicated to the War Dead. According to Kiyama Terumichi, Deputy High Priest of Yasukuni Shrine:

After the defeat in the war, relations between Yasukuni and the State and between the shrine and the people's consciousness have been treated as if they were political issues. When the Prime Minister comes here to pray, it becomes an issue whether he's at the shrine as a private or as a public personage. From the Yasukuni Shrine's perspective, it is not our intent to be involved in political issues. We merely pray and express our thanks to the spirits. ${ }^{24}$

Yasukuni Shrine provides a venue for Japanese to come close to the spirits of their loved ones, and at the same time, to express the sentiments they feel as survivors. Yasukuni serves both the living and the dead. Directly linked to the Shrine's special place in pre-war and wartime mobilization themes and the promise of a 'Return to Yaskuni', those who died in war for the Emperor and the Nation are enshrined there. For the living, Yasukuni holds the meaning of the dead in a sanctuary, free and uncontaminated by what historians may see as the realities of war. For many families, Yasukuni serves as the focus of the spirit of their loved ones, but it matters less that their loved one is enshrined there than that this 'sacred space' is set aside for them to discuss, remember, share their good memories with others of similar circumstance. This space for the Dead is privileged, and any criticism of the dead seems out of place there. An implication of this is that to speak ill of the state, of the war, means direct criticism of the dead themselves in the minds of most people whose family members 'fell' in the war.

The government pays substantial pensions to the living veterans of that war, and survivor's benefits to the families of dead soldiers and sailors. The rates paid are based on the soldier's rank at the time of their retirement or death (incorporating an automatic two-rank promotion of the dead!). Even war criminals - those convicted of war crimes by the Allies after the war - are compensated by Japan's treasury. Dead sons are helping out their aged mothers and fathers decades after the war through this 'money paid to the family of the war dead'. This, of course, may be interpreted as the nation silencing critical voices with payoffs. Yet to the recipients, the money is coming from the dead. ${ }^{25}$

There are some people who feel obliged to testify in contravention of the notions laid out above. One group that stands out in its efforts and courage are the members of the Association of Returnees from China. These are the men who admit their role as perpetrators of crimes and are willing to speak about them. They are people who have fully confessed what they did and have been speaking out about what 
Japanese people did in Asia. They clearly place responsibility on the Emperor, while not denying their own culpability. Found guilty of war crimes, they were spared by the People's Republic of China.

When they returned home, many were accused of having been brainwashed by the Communists when they expressed their regret at what they had done. They often found themselves cold-shouldered by other veterans and had great difficulty finding work, not because they were war criminals, but because they spoke of their deeds. ${ }^{26}$ These men see the Chinese Communists as having spared them, despite what they deserved. For that reason, when incidents like the Tiananmen Square Incident occurred they could not believe what they were witnessing. Their association was on the verge of sending a delegation to China and was torn apart by the issue of whether what the Chinese government was doing could absolve them of their own debt to the Chinese people and to the China that had spared them. Today's politics was opening an old wound. Their voice is often muted, when, even when they have already contracted for a room, they find such agreements reneged on at the last moment for inexplicable reasons. Now, in the wake of Tiananmen and the ideological confusion of left and progressive groups everywhere, their already weak position has been significantly eroded. The experiences of the people we spoke to were tremendously varied, but one theme, one phrase, was repeated again and again: 'What a stupid war it was', 'I hate war', or 'We shouldn't fight war anymore'. Nishihara Wakana put her sentiments particularly eloquently:

I'm frightened of ideology, of -isms and of nations. I prefer an unjust peace to a justified war. No matter what the ideals are, if they are going to lead to war, I prefer a corrupt, immoral, unprincipled, unredeemed peace. ${ }^{27}$

The war reflected in their memory seems to be a war that somehow came to them, like a natural disaster, an earthquake or tsunami, something about which they had little choice. The enemy, especially the American enemy, does not seem to play a major role in their memory. If they are not responsible individually, who then is responsible?

\section{Defining the legacies of a Lost War}

A former army officer, Mogami Sadao, acknowledged that Japan had fought a "stupid war", the rivalry of Army and Navy leaders leading in his mind to the deaths of two million military men. But he took great solace in the words of a wealthy Chinese from Singapore, a man whom he had sought out as a client in his post-war life as a representative of the great British trading company Jardine Matheson, based in Hong Kong. 'Freedom, equality, philanthropy, these things were all only for the sake of Caucasians before. To conduct a revolution in thought, 
which would bring these things to everybody, to all humankind, that was the achievement of the Greater East Asia War.' On such foundations this Japanese pilot, a senior official in the Association of Officers of the Former Imperial Army, built his own assessment of the war,

But Japan was able to recover from the war in all respects afterwards because the people's mind was united, bound up together, and all the race's energy was combined. Today's Japan might not exist if Japan had not stood up at the time of the Japan-US negotiations. If Japan had weakly submitted then, none of this might have been possible. I do not glorify war. I know you shouldn't fight war, but if it happens, what matters are the lessons you learn from it! ${ }^{28}$

Instead of unwrapping Japan's memory, this operates in the opposite direction. With the exception of several hot issues, specifically the 'comfort women' forced into sexual slavery in the service of the Japanese military and a fuller appreciation of Japanese cruelty in China and among prisoners of war, there has been little willingness to foster a full and open discussion of what actually happened in the war.

As mentioned above, the precise dating of the beginning and the ending of the war may be somewhat problematical inside Japan, but by conforming to anniversaries and dates chosen by the nations Japan fought in the war, such commemorations as take place can be kept within the memorial realm, rather than being allowed to solicit full discussion of the war experience and the "realities of war'. Individual war testaments, recollections, and short memoirs may occupy a corner of the bookstores, but they are not at the core of modern Japanese historical writing or analysis of modern Japan

Former officers in the Imperial Japanese Army have acted collectively, through their association the Kaikōsha, to impart their legend. When it sold its former headquarters, the land and building, which were in a very desirable location in Ichigaya, Tokyo, were exchanged for offices closer to the Yasukuni Shrine. The association then contributed a huge sum of money to the Shrine from their profits. In recent years Kaikōsha has been active in historical work, publishing its own three-volume history of the Nanjing Incident - prepared and written by former officer-historians - and collaborating in a history of the Special Attack Forces. ${ }^{29}$ Closely coordinating their efforts with Yasukuni - especially the official Memorial Hall at the Shrine - this association, and other groups directly connected to the units and localities involved, have sought to publicize their story of the young men who 'gave their lives' as Kamikaze pilots in the final stages of the war. Kaikōsha has long worked to protect the Army and themselves by using evidence of their own choosing to argue in the historical arena against those whom they view as besmirching the reputation of the Imperial forces. They see themselves as having a virtual monopoly on knowledge of the events - their 
longstanding association with official history organizations in the Japanese Self-Defence Forces has made their view an important part of Japan's official war history. Something similar can be said for the former officers of the Imperial Navy, but their central organization, the Suikōkai, unlike the Kaikōsha, is not a closed group, open only to the dwindling ranks of Imperial Army men or officer rank, but is dedicated to naval affairs, and incorporates men from Maritime Self-Defence Forces as well as the Imperial Japanese Navy.

Ian Buruma, in his intriguing study comparing notions of guilt in Germany and Japan, has recently afforded us insight into a number of the museums devoted to aspects of the war in Japan. He aptly characterizes the Memorial Hall on the grounds of the Yasukuni Shrine, with words that may be applied to many of the less extensive edifices as well: 'What it glorifies in a quasi-religious manner is not belligerence or hatred, but self-sacrifice. ${ }^{30}$ At Yasukuni and Chiran - the site of the Peace Museum for Kamikaze Pilots, near Kagoshima in southern Kyushu from where many of the Special Attack planes departed for their strikes at the Allied fleets off Okinawa - that theme of glorified self-sacrifice becomes foremost in efforts to engrave a legend of the universal self-sacrifice of a wartime generation, venerated eternally by a grateful nation, on the future. The faces of a lost generation look out at the living, reminding them of what these young people gave up, and perhaps admonishing them kindly for any thoughts the viewer may have had of letting them slip away into obscurity.

Universality is essential to this notion of the legend and it is shown in stone and bronze at many of the memorial sites. At the southern tip of Okinawa, where some of the most savage fighting took place in 1945, the visitor is greeted by a vast array of stone monuments, each surrounded by a patch of open ground around a central stone, obelisk, or monolith. Each year associations of the survivors of the battle and the families of the dead make pilgrimages to the location on the anniversary of the Battle of Okinawa to pray and to burn incense for the spirits of their comrades or family members. The sheer number of the monuments underscores the scale of the wartime effort, to be sure, and the geographic diversity of the soldiers and sailors who took part in the battle seems to bind Okinawa closer to the Homeland. Yet, although universality may be a theme, the method chosen to express it is most particularistic. The monument stones are dedicated to the war dead of a particular prefecture or part of the country of Japan. To the exclusion of any serious presentation of differences between the experience of Okinawan civilians and Japanese soldiers, each military unit is represented individually, and the military forces engaged in the battle for Japan's southernmost prefecture stand guard as if separate sentries.

Nearby, stands the Himeyuri Peace Memorial Museum, built several years ago through the efforts of survivors of the 'Himeyuri [Lily] Student Corps' - student 'volunteers' from the First Okinawa Prefectural Girl's High School and the 
Women's Division of the National Okinawa Normal School, aged between 15 and 19 , who served as student nurses during the battle. In this museum, enlarged black and white photographs of young girls who were killed adorn the walls, each identified by name; some of the girls whose names are mounted have no photos to accompany them, almost making their loss seem more pitiable. The similarity of the presentation to the array of young warriors at Yasukuni and Chiran is striking. Yet, rather than honouring them for 'self-sacrifice', this museum for the elite girls of wartime Okinawa centres on the tragedy of their loss. The brevity of their lives and the sadness of their deaths are attributed to 'War'. Testimonies of survivors are on display, as are lunch boxes, fountain pens, combs, writing boards, pencil boxes, and other artefacts dug out from the caves where the students worked. The museum itself is built above one of the caves. This museum tells the story of this one group to throngs of school children and tourists who come to visit. Nothing is said here of the girls from other Okinawan schools who found themselves in similar situations. Nor is their mention of the mass of other civilians - families, old men, and women with small children - forced out into the 'typhoon of steel' to make way in caves for the nurses and the soldiers during the battle. ${ }^{31}$

In the 1995 ceremonies commemorating the end of the battle of Okinawa, the Governor of Okinawa, Ohta Masahide, was instrumental in the creation of a new memorial to all the dead of the Okinawa fighting, dedicated on the anniversary of the official end of that battle. ${ }^{32}$ The 'inclusiveness of suffering' was expanded and extended even to the American and Korean dead. The individual names of all the dead were read aloud and the black stone-faced monument, similar in appearance to the Vietnam Memorial in Washington, DC, was embossed with the names of all known to have died, military and civilian. The place set aside for Koreans was particularly poignant.

At the same time, many living survivors of that war are nearly forgotten, and individual memories of the living have been allowed to play a subordinate position to that accorded to the dead. As we have shown, in the case of some of the living - Japanese prisoners of war and civilians reported to have killed themselves in Saipan - their survival is almost an embarrassment. For others, afflicted with what has widely come to be called 'survivor guilt', a nearly inexplicable escape from the death that seemed to enmesh them (whether in a southern jungle or an atomic flash) has created a kind of linkage with the dead that has been allowed to continue longer than may be healthy for Japan.

What is most lacking in today's Japan is a place for those living in the war years fully to express themselves in their diverse and conflicted voices. They must be freed from the dead. Constrained from speaking openly about the war by friends, families, and loved ones, they need to be drawn out to testify to the war experience before their voices are lost. However stark, unpleasant, desolate, or incriminating to the Official Memory of the War their personal living memories may be, Japan 
and the world at large need them to convey what they have kept wrapped and hidden away.

\section{References and Notes}

1. H. T. Cook and T. F. Cook (1992) Japan at War: An Oral History (New York: New Press; paperback 1993), p. 3. We discuss a number of the experiences we encountered in the course of our four years interviewing and researching for that book in our introduction in our search for a lost war.

2. One fine summary of the work on memory that has increasingly expanded our understanding of this powerful term is the introduction and opening chapter of P. H. Hutton (1993) History as an Art of Memory (Hanover and London: The University of Vermont), pp. xi-xxv, 1-26. In the introduction to his diagnostic study of the conflicted and bitter experience of the Second World War and Vichy in French memory since 1944, Henry Rousso defined the history of memory as 'the study of the evolution of various social practices, and more specifically, of the form and content of social practices whose purpose or effect is the representation of the past and perpetuation of its memory within a particular group or the society as a whole'. Yet, the history of memory may also be associated with events like the French Revolution or Second World War 'whose memory survives long after the last flames have been extinguished and whose influence extends over the whole of society,' He writes, ' ... Historians are interested not only in ascertaining the facts about such events but also in comprehending their persistence.' H. Rousso (1991) The Vichy Syndrome: History and Memory in France since 1944 (Cambridge: Harvard University Press), p. 3,

3. See the work of P. Nora (ed) (1984) Les Lieux de mémoire, vol. 1; (1986) La République; vol. 2: La Nation (Paris: Gallimard), vol. 1, p. xv. Quoted in Ibid., p. 3. See too, J. Winter (1995) Sites of Memory Sites of Mourning. The Great War in European Cultural History (London: Cambridge).

4. See the excellent summary of some of the key literature on memory and the commemoration of the First World War in A. Gregory (1994) The Silence of Memory: Armistice Day 1919-1946 (Oxford/Providence: Berg), pp. 1-7.

5. Throughout our work we have sought to contrast Japanese memories of the war to the memories of victims of incarceration in Japanese camps, citizens of occupied areas, including Korea, and the experience of ordinary Japanese residents of the external empire, including the Pacific islands, Taiwan, Okinawa, and the continent of Asia.

6. S. Hynes (1991) A War Imagined. The First World War and English Culture (New York: Atheneum), pp. xl-xlv. He entitled his introduction 'A Gap in History'. Also essential to understanding the impact of the war is P. Fussell (1975) The Great War and Modem Memory (New 
York: Oxford University Press) the classic of literary memory and the First World War. The Second World War presents great difficulties for those who seek to examine it. P. Fussell (1989) Wartime. Understanding and Behavior in the Second World War (New York: Oxford University Press) stresses the 'psychological and emotional culture' of British and American soldiers in the Second World War, seeking to release the experience from what the author considers the euphemisms and rationalizations that shroud the Second World War story. It is also illuminating to think of Fussell's own emotional rationalization as expressed in his 'Thank God for the Atomic Bomb' essay published several years ago. G. L. Mosse (1990) Fallen Soldiers. Reshaping the Memory of the World Wars (New York: Oxford University Press), pp. 7-8, looks at the shrouds that drape the dead, literally, and explores the ways how, what he expressly labels 'the Myth of the War Experience', emerged through the First and Second World Wars. L. L. Langer (1991) Holocaust Testimonies. The Ruins of Memory (New Haven: Yale University Press) deals with efforts to recover the memories of survivors of the Holocaust. What emerges is the notion of ruins of memory, and types of memory, ranging across five forms of memory: deep memory, anguished memory, humiliated memory, tainted memory and unheroic memory.

7. We can see a different order of interpretation of war experience in J. W. Dower (1993) The useful war. In Japan in War \& Peace. Selected Essays (New York: The New Press), pp. 9-32. He stresses the utility of actions taken in the war years in the recovery and development of Japan after 1945. For Germany's experience in dealing with Second World War legacies, see C. S. Maier (1988) The Unmasterable Past. History, Holocaust and German National Identity (Cambridge: Harvard University Press) for a deep discussion of the notion of a usable past and questions of responsibility raised in Germany earlier by such historians as A. Hillgruber (1981) German and the Two World Wars (Cambridge: Harvard University Press).

8. We deal with this problem throughout Japan at War: An Oral History. See the discussion of those images in J. W. Dower (1986) War without Mercy: Race and Power in the Pacific War (New York: Pantheon). He summarizes many of these themes in 'Race, Language, and War in Two Cultures,' in his Japan in War \& Peace. Selected Essays, pp. 257-285.

9. Those who reached school age during the conflict, were deeply influenced by the narrowness of wartime rhetoric and perceptions. The very young were able to replace or supplement the vocabulary and thought forms of the war by rapid absorption of outside, external vocabulary and ideas under the Occupation. It is arguable that both persist in their minds long afterwards.

10. J. W. Dower (1986) War without Mercy: Race \& Power in the Pacific War (New York: Pantheon Books), pp. 231-33 and 352-353, notes 61-64, discusses one interpretation of the origin of gyokusai and its development. He dates the phrase 'ichioku gyokusai' [the shattering of 
the hundred million like a beautiful jewel] from April 1945. Actually, it appeared at least as early as 24 June 1944, when it was used in the Daihon'ei Kimitsu Sens Nisshi that day, see M. Hirosuke (1992) Higeki no Sainan. Zettai KokubOken no hōkai [The Tragedy of Saipan: The Collapse of the Absolute Defense Zone] (Tokyo: Futowaaku Shuppansha), p. 118.

11. K. Kiyoshi, Ankoku Nikki 1942-1945 [Diary of Dark Days, 1942-1945], 39-40. On 31 May 1943, Kiyosawa Kiyoshi noted in his diary that following the previous day's broadcast of the news of the gyokusai of Japanese forces on Attu by Imperial General Headquarters, 'Today's papers tell us that at the end only a hundred and a few score remained, that the wounded committed suicide, and the healthy charged [into the enemy].' Rather than accept the story, Kiyosawa set down in his diary the thought 'If they were not people related to the military, the following questions would come up and become social problems'. Criticizing such events, he asks why Headquarters did not dispatch more men, although it was reported that Colonel Yamazaki did not request even one more soldier. 'Isn't the lack of reflection of their strategy leading to all strategic failures?' he asked. What is the meaning of 'gyokusai-ism' - a phrase he coined - as seen on Attu? 'Next it will be Kiska,' he wrote. 'It appears we have one division there [Kiska]. Gyokusai-ism will deprive them of their lives. Is this good for the nation? This will be an issue in future. The general public may not make any inquiry into such things. Oh, stupid general public!' Perhaps Kiyosawa was able to foresee what lay ahead for the people of Japan. While the High Command did eventually evacuate the Kiska garrison prior to an American descent on the island, Kiyosawa remained angry at the Japanese public for their seeming indifference to news he felt should have shocked them into demands for clarification. K. Kiyoshi, Ankoku Nikki 1942-1945 [Diary of Dark Days, 1942-1945], pp. 39-40.

12. While news of gyokusai on Saipan spread through the main islands of Japan, wounded and starving soldiers were still wandering in the mountains of Saipan chased by US strafing until they were made into 'war dead' or fell into enemy hands. Thousands of non-combatants were also still roaming until they were captured by, or surrendered to, the US forces. Final figures for Japanese casualties on Saipan vary considerably, with American sources identifying 23811 'enemy buried' and 1780 captured (838 Koreans), with some 14560 civilians taken into custody. S. E. Morison (1953) History of United States Naval Operations in World War II, V, 339. See also K. Kiyotaka (1989) Taiheiyō sensō no rekishi (History of the Pacific War), vol. 2 (Tokyo: Kōdansha), pp. 143-146 and Japan at War, pp. 291-292.

13. Noda Mitsuharu, interview with the author.

14. Suzuki, p. 206.

15. N. Field (1991) In the Realm of the Dying Emperor; A Portrait of Japan at Century's End (New York: Pantheon) refers to one such person in her extremely perceptive study of Okinawan memories of the war, citing 
how the 'rare' survivor of Saipan carried the warning of what lay in store for the inhabitants of Japan's southernmost prefecture prior to the American landings in April 1945.

16. 'I have always considered Saipan the decisive battle of the Pacific offensive,' wrote Holland M. ('Howling Mad') Smith, the Marine Corps general who commanded the assault that began on 15 June 1944. As he contemplated the 16525 US casualties, including 3426 killed and missing, suffered by the 67451 men of his command, Smith declared after the war that its seizure made Allied victory absolute. H. M. Smith and P. Finch (1949) Coral and Brass (New York: Scribner), pp. 181-182 quoted in S. E. Morison (1953) History of United States Naval Operations in World War II, Volume 5, New Guinea and the Marianas March 1944-August 1944 (Boston: Little, Brown and Company), pp. 339-340. Such views of the importance attached to Saipan by Tokyo may be seen in many official and semi-official sources, for example C. W. Hoffman (1950) Saipan: The Beginning of the End (Historical Division HQ, U.S. Marine Corps), J. A. Isely and P. A. Crowl (1951) The US Marines and Amphibious War (Princeton: Princeton University Press), P. A. Crowl (1960) United States Army in World War II. Vol. 2. The War in the Pacific. Part 9. Campaigns in the Marianas (United States Army, Office of Military History).

17. The International Herald Tribune, June 24, 1994.

18. See the timely study by I. Buruma (1994) Wages of Guilt Memories of War in Germany and Japan (New York; Fararr Straus Giroux).

19. See T. F. Cook, Jr. (1983) Cataclysm and career rebirth: the imperial military elite. In D. W. Plath (ed), Work and Life Course in Japan (Albany: State University of New York Press), pp. 135-152.

20. Although there are some, like Andrew Barshay, who will maintain that a Japanese intellectual like Nanbara Shigeru (1889-1974) could in wartime be what he calls 'a responsible witness', such a notion is ultimately quite specious. No matter how many poems he may have penned, or diary entries scriven, ultimately Nanbara and many other writers and thinkers who were not actively committed to the war effort were something less than witnesses. They hid from events, profited from their positions, and ultimately made little contribution to efforts to avoid, or end, the war. A. E. Barshay (1988) State and Intellectual in Imperial Japan: The Public Man in Crisis (Berkeley, CA: University of California Press), p. 108

21. Perhaps the most notable exception was the Japanese Communist Party, whose members, most released from jail only in 1945, were among the first to criticize the entire pre-war and wartime regime and to denounce the Emperor's role in the war. Progressive scholars of various political persuasions, including the political scientist Maruyama Masao, authors like Noma Hiroshi and Ōoka Shōhei, film makers Kobayashi Masaki, and the mural paintings of Maruki Toshi and Maruki Iri, and rare individuals like Ienaga Saburō, who has conducted a one-man crusade on the subject of how the war should be treated in school textbooks, 
must be mentioned. But on the whole, most such efforts did not kindle widespread debate or reassessment.

22. It was interesting that the end of the Shōwa era, with the death of Emperor Hirohito on 5 January 1989, whose reign had lasted just over 63 years, while accompanied by a vast outpouring of 'Shōwa History' compendiums, was not accompanied by any detailed re-examination of the years of his reign. Especially conspicuous by their absence, were critical new assessments of the war years and the Emperor's role. See especially Norma Field's survey of Japan in 1988 and 1989, In the Realm of a Dying Emperor and Ian Buruma's The Wages of Guilt. There was no clear impact of the Emperor's death on the project in which we were engaged. For some of the people we spoke with around this time, the Emperor's death contributed to the sense of an epoch passing; for others, that date underlined their own mortality, and left them with a desire to release what they had been holding inside - if not to confess, at least to confide. At the same time, others took the Emperor's death as a moment to put the whole war behind them rather than to reflect on its meanings.

23. Japan at War, pp. 319-327. She described the lingering effect of those flights overhead, 'My grandson says, 'Grandma always looks up when a plane flies over'. I look up because it's as if the Tokkō planes are overhead as they once were, 45 years ago. That won't ever change ...' (pp. 326-327).

24. Japan at War, p. 449. Of course, in his interview with us, Deputy High Priest Kiyama went far beyond his own 'rules of engagement'.

25. Japan at War, p. 477.

26. See Japan at War: An Oral History, pp. 462-468 for one man's experience.

27. Japan at War, p. 336.

28. Japan at War, p. 458.

29. Nankin Senshi Hensh Iinkai (ed) $(1989,1994)$ Nankin senshi History of the Nanking Battle, 3 vols (Tokyo: Kaikōsha).

30. See I. Buruma (1994) The Wages of Guilt Memories of War in Germany and Japan (New York: Fararr Straus Giroux), p. 223. We have visited the memory sites in Japan he discusses in his chapter on 'Memorials, museums, and monuments', pp. 202-238 and share what we sense is a deep concern with the direction these memorializations are taking. We were also struck in a similar manner by the Poison Gas Museum on Okunoshima in the Inland Sea, not far from Hiroshima. In its isolation on 'the island that was erased from the map' it seems a particularly stark relic of the war years. See Japan at War, pp. 199-202.

31. This creation of monuments has spread beyond Japan as well, as any traveller to Southeast Asia or the sites of Second World War battles can attest. One side-effect has been to find Japanese monuments standing next to, or among, those of their wartime adversaries. On at least one occasion, though, the former enemy's story has been shoved aside. Otto Schwarz, the head of the Blue Bonnet Society, the US Navy veterans' group of the USS. Houston (sunk in the Battle of the Java Sea in early 
1942), told us of how his group was unable to erect a monument in Burma (where many of the survivors taken prisoner were forced to work on the infamous Burma-Thai Railroad) when they were unable to pay the huge 'donation' requested from the government. The site they had selected was soon home to an impressive memorial to Japanese soldiers killed in Burma erected by Japanese veterans, presumably after having assured the host government of their willingness to make the necessary 'contribution'.

32. Ohta Masahide was a youth during the battle for Okinawa, enrolled in the 'Blood Iron Student Corps' and employed mainly as a courier. A noted historian of the Battle of Okinawa and Okinawan history and culture, before he was elected Governor of Okinawa in 1990, he described his wartime experiences and the frustrations of living in post-war Okinawa, first under American rule, and then Japanese, in Japan at War, pp. 367-372, 458-461. The Governor has continued to press his case for a withdrawal of American forces in an escalating conflict with the National government in Tokyo.

\section{About the Authors}

Haruko Taya Cook is Assistant Professor of History at Fordham University, Marymount College, Tarrytown, New York. She is co-author of Japan at War: An Oral History (New York: The New Press, 1992). She was awarded a National Endowment for the Humanities grant for research on Japanese Women and the 'Greater East Asia War' and is currently examining that war as understood and experienced by Japanese during the conflict.

Theodore F. Cook is Professor of History at the William Paterson University of New Jersey. He has been a Visiting Professor and Secretary of the Navy. Fellow at the US Naval War College and a Visiting Professor at the Australian Defence Force Academy and serves on the Advisory Group for the Centre for Second World War Studies at the University of Edinburgh. He is co-author of Japan at War: An Oral History, and is writing a history of the Imperial Japanese Army and is collaborating on a study of Japan during the Asian and Pacific War. 
